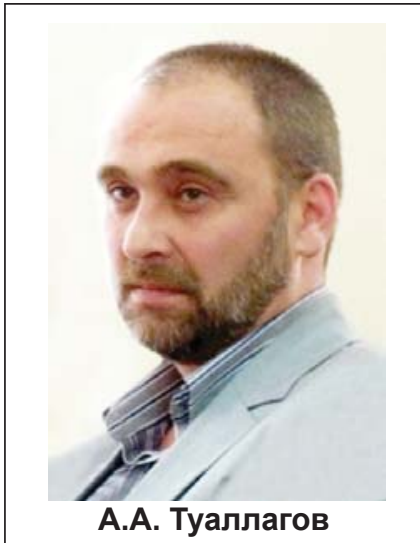

Начало истории создания единой оборонительной линии на Кавказе, охранявшей северные рубежи различных империй, было связана с деятельностью Персии эпохи правления Сасанидов. Иx Limes Sasanicus, в конечном итоге, протянулся от Дербента до территории современной Абхазии. Он включил в себя, в том числе, и укрепления, расположившиеся в непосредственной близости или на территории владений алан.

Переговоры по вопросу о создании укреплений в районах Дербента и Дарьяла, для чего Рим готов был платить Персии, велись еще при Феодосии I (379-395 гг.) [29, р. 87 , п. 2]. Переговоры о мирном договоре велись и при Ездигерде I (399/400-421 гг.) [27, р. Р. 143]. После переговоров между Персией и Византией в 413-414 г. был заключен мирный договор. Он касался, в том числе, обороны горных проходов, через которые совершались вторжения во владения обеих империй. С ним связывают свидетельство Иоанна Лаврентия Лида [28, р. 244-245] о достигнутой договоренности с Византией при персидском правителе Ездигерде I (399/400-421 гг.), что обе империи, неся равные расходы, построят крепость, закрывающую горные проходы и препятствующую вторжению гуннов. Речь шла о построении крепости, которая станет известной как Дарьяльская [18, с. 245-248].

По ал-Табари, персидский правитель Пероз (457484 гг.) построил каменную крепость во владениях алан. Эпиграфические, археологические и письменные источники позволили полагать, что речь шла о закладке известного Хумаринского укрепления в верховьях Кубани. Если Дарьяльское укрепление закладывалось рядом с владениями мощного аланского объединения, то Хумаринское - непосредственно на территории такого владения [26, р. 82-83].

Кавад I (488-531 гг.) после утраты на некоторое время Дарьяльского укрепления вновь захватил его. Ал-Баладури [3, с. 330] и Ибн ал-Факих ал-Хамадани [20, с. 11] сообщали об укреплении Кавадом I персидской оборонительной линии от Дербента до Дарьяла. По сообщению Себеоса, Хосров І Ануширван (531578 гг.) укрепил, запер Аланский проход [4, с. 81; 7, c. 36]. Ал-Баладури также указывал, что персидский правитель наряду со многими другими местами укрепил Баб ал-Лан, построил там крепость [3, с. 330]. О постройке им крепости сообщали Ибн ал-Асир, Ибн ал-Факих ал-Хамадани и Ибн Хордадбех [10, с. 10; 20, c. $15 ; 8$, c. 109].

В списках XI в. «Мокцевай Картлисай» сообщается о проникновении при Хосрове I Ануширване персов в горы Кавказа, где они построили, в том числе, большие врата в Осетии и Двалии, поставив охранниками там местных горцев. В редакции «Мокцевай Картлисай» Х в., обнаруженной в четырех списках в 1994 г. в монастыре Св. Катерины (Синай, Египет), сообщается о сооружении персами Ворот Осетии и оборонительной стены Клисура, большей, чем Ворота Хазар (Дербент) [25, р. 677]. Данное сообщение справедливо рассматривается как косвенное свидетельство в пользу «сасанидской версии» укрепления Хумары. В целом, обоснованно пересматривается и обычное в исследовательских работах положение о сугубо провизантийской ориентации алан Северо-Западного Кавказа. Отношения здесь Алании, Византии и Персии были гораздо более сложными и динамичными [5, с. 58-63].

Исследователи обратили внимание на Хилакский оборонительный комплекс (стена и башни) в Куртатинском ущелье современной Северной Осетии. Техника строительства укрепления и сама практика расположения укрепления по обоим берегам горных рек была сопоставлена с памятниками типа Верхнечирюртовского городища, которые сооружались персидскими правителями [22, с. 130-132], стремившимися обезопасить свои закавказские владения от набегов с севера. Именно против северной угрозы была поставлена и Хилакская стена, а также, видимо, и другие стены в Куртатинском ущелье. Техника возведения Хилакского укрепления сопоставима и с Дарьяльским укреплением [14, с. 4], и с Касарским комплексом, что соотносится с приведенным сообщением «Мокцевай Картлисай» [13, с. 181; 21, с. 59-60, 62-63]. К сожалению, так и остается неисследованной заградительная стена в районе Кахтисара, разделявшая Кобанское и Даргавсское ущелья. 
Практика персов привлечения местного населения для охраны собственных укреплений не ограничивалась только выявленными рубежами. Например, материалы поселения и могильника Едыс VI-VII вв. в Южной Осетии позволили предполагать здесь поселение группы алан, выполнявших наемные функции охранников. Такие ограниченные контингенты алан появляются и в Восточной Грузии - Мцхета, Жинвали, Агайани, Алеви [6, с. 71-81].

Персы стремились наладить отношения непосредственно с аланской знатью. Об этом свидетельствуют богато инкрустированные камнями шарнирные бляхи из погребения V в. в Гиляче, из богатого погребения у г. Кисловодск и в гробнице Кишпека [11, с. 103], а также драгоценные, социально престижные предметь из могильника Брут I, которые рассматриваются как дипломатические дары, выполненные с учетом вкусов алан. Они, как и другие престижные сасанидские импортные вещи, например из Дагомского могильника или Урсдонского ущелья, рассматриваются как дары, плата или военная добыча [19, с. 48-51]. Haходки иного импорта указывают, с одной стороны, на специальную ориентированность производителей на местное население; с другой стороны, на военно-политические, культурные и экономические связи между персами и аланами [17, с. 128-129, 180-181].

На Северном Кавказе известны находки около 100 сасанидских и арабо-сасанидских монет. Около 80 найдено в Придарьялье. Монеты непрерывно поступали сюда, как полагают, за счет приноса аланами из Закавказья, где, например, в Восточном Закавказье (Картли) сасанидская драхма была основной единицей монетного обращения. Полагают, что часть драхм попала к местному населению во время строительства персами укреплений в горах Осетии [19, с. 67]. Находки сасанидских монет в горных районах, включая Осетию, связываются с таможенной пошлиной [24, c. 140].

Известно, что Персия и Византия неоднократно нанимали за значительные денежные суммы воинские силы алан для выполнения тех или иных боевых задач. Часть находок сасанидских монет в аланских погребениях явно использовались не по назначению, а в качестве амулетов, талисманов или украшений. Но вряд ли поступавшие в Аланию большие суммы предназначались исключительно для подобного применения. Некоторые дополнительные наблюдения позволяют рассматривать их в качестве средств платежа [16, с. 50-52; 23, с. 58]. Не исключено, что часть алан выступала в роли торговых посредников или была, по крайней мере, втянута в товарно-денежные отношения.

Что касается пошлины, то она могла взиматься только в пользу Персии, т. к. именно ей принадлежали в то время оборонительные укрепления, защищавшие северные рубежи империи на Кавказе. Аланы могли получать по договору долю от пошлины или фиксированную оплату, включаясь в гарнизоны укреплений. Таким образом, они могли выполнять одновременно и таможенные функции, тем более, что торговые кара- ваны сочетали в себе как собственно торговые, так и военные функции. Поэтому аланы должны были привлекаться определенными материальными благами со стороны нанимателей, поставляя со своей стороны профессиональных воинов с соответствующим вооружением и навыками его применения. Немаловажным фактором должна была стать адаптация алан к несению службы в горных условиях

Созданная Персией Limes Sasanicus от Дербента до Абхазии заложила прочную основу разделения имперского Юга от Севера. Она во многом была унаследована Арабским халифатом, также вынужденно пришедшим к необходимости укрепления здесь своих рубежей, будучи не в силах, как Персидская и Византийская империи, победить или сколь-нибудь надолго закрепиться там. Важное место в данной линии, несомненно, должны были занимать и укрепления в горных районах современной Северной Осетии.

По ал-Баладури, Дарьяльское укрепление было захвачено Йазидом б. Усайд ал-Салами около 758 г. В Дарьяльском укреплении была размещена конная стража из наиболее верных воинов с регулярным денежным содержанием [3, с. 331]. Ал-Масуди сообщал, что замок Аланских ворот охранялся арабским гарнизоном, получающим провиант из тифлисского пограничья, с тех пор, как Маслама б. Абд ал-Малик б. Марван пришел в страну алан и покорил ее народ [3, с. 347-348]. Согласно «Жизни Вахтанга Горгасала», Ворота Дариала были захвачены Мурваном Глухим в 735/736 г. [3, с. 415]. По ал-Табари, Марван б. Мухаммад в 737 г. послал экспедицию, которая захватила три крепости в стране алан [3, с. 355]. Гипотетически одну из взятых крепостей идентифицируют с Дарьяльским укреплением [11, с. 114-115]. По ал-Якуби, в 727-728 г. поход против тюрок совершает Маслама. Он преграждает им путь у Ворот Аллана и сталкивается с хаканом. По другому варианту, он захватывает у тюрок Ворота Аллана [9, с. 6, 7]. Несомненно, под тюрками подразумеваются хазары.

Судьбу Дарьяльского укрепления, видимо, разделил и Касарский оборонительный комплекс. Появление здесь арабского гарнизона исторически связывают с арабо-хазарской войной 763-764 гг., когда хазары совершили опустошительный поход в Закавказье. По сообщению ал-Йакута, тогда арабы выпустили из тюрем 7000 заключенных, собрали воинов, присоединив к ним рабочих и строителей, и отправили против хазар. Они построили города, превратив их в опорные пункты для мусульман, поселив там воинов. Благодаря этим городам мусульмане усилились, а страна успокоилась.

С определенной осторожностью можно предположить, что Касарский комплекс был в числе тех, которые укрепили арабы для сдерживания прорывов хазар. О контроле здесь арабов, как полагают, может свидетельствовать само название «Къасара» (араб. къасара - «крепость», «замок», «дворец») и материалы могильника Мамисондон [2, с. 132-135]. Полагали, что «Касарская оборонительная стена» служила последним участком кавказского лимеса на стыке двух 
миров, что соответствовало территории, занятой сначала Сасанидским Ираном, а потом Арабским халифратом $[15$, с. 49,52$]$. Что касается Хумаринского укрепления, то оно перешло под контроль хазар.

Создание Limes Caucasus имело и другие важные последствия. Например, долгое подчиненное положение Картли в составе персидской и арабской провинций принесло и некоторые положительные результаты. Долгое объединение завоевателями Картли в одну провинцию с лежащими к югу от нее горными территориями с иноэтничным независимым населением привели к сближению и постепенному проникновению в горные районы грузиноязычного этнического элемента, медленно ассимилировавшего здесь, например, нахоязычные народы.

Видимо, подобный процесс протекал и на Севере. Он способствовал интенсификации освоения здесь горных территорий аланами, долгое время входившими в состав «лоскутной империи» Хазарии. Если судьба немногочисленных аланских групп в Закавказье, нанимавшихся на охранную персидскую службу, была связана с отрывом от родины, то погранично-таможенная служба на Северном Кавказе стимулировала, наряду с вероятными иными причинами, продвижение алан в горные территории, которые становились неотъемлемой частью собственно Алании. Таким образом, заложенная персами граница, в конечном итоге, сыграла свою положительную роль в истории алан. Поэтому нет ничего удивительного в том, что позднее такие мощные укрепления на Севере, как Дарьяльское и Касарское, оказались в руках самих алан.

В целом, для алан заметно расширялся круг и интенсивность межэтнических, культурных и иных взаимодействий. Недавно была выдвинута интересная гипотеза о переселении алан во второй половине VIII в. в рамках политики Хазарского каганата из района Кисловодской котловины не только на территорию бассейна Среднего Дона, но и Кубани и в горные районы Дарьяла. Здесь они охраняли рубежи Хазарского каганата, неся и таможенную службу. В Х в. заметная часть алан вернулась с Северного Дона на Северный
Кавказ, видимо, в том числе в районы Кисловодской котловины и Дарьяла [1, с. 202-206].

Хронология событий вполне допустима, поскольку со второй половины VIII в. граница между Хазарским каганатом и Арабским халифатом стабилизируется. Фактически каганат использует опыт персов и арабов, выстраивая свои оборонительные рубежи, не только выдвинутые к рубежам персидской, а затем арабской оборонительных линий, но и выводя их гораздо далее на север для решения новых военно-политических и торговых вопросов. Соответственно, используется имевшийся опыт привлечения к охранно-таможенной службе алан не только на северокавказских границах халифата, но уже в массовом порядке на севере, в районы рр. Дон, Тихая Сосна, Северский Донец и Оскол, что значительно расширяло географию службы, межэтнических, культурных и иных взаимодействий алан, своего рода раннесредневекового казачества. Несомненно, такое положение должно было сказаться и на развитии самого аланского общества. Как отмечали исследователи, здесь аланы расселялись в местах, в природно-географическом плане напоминавших их северокавказскую родину.

Отметим, что еще во II-IV вв. аланы имели собственный опыт возведения поселений и крепостей, в том числе составлявших единые оборонительные районы. Таким районом являлась, например, Кисловодская котловина, где аланы организовали свой limes из пограничных крепостей и сигнально-сторожевых постов. C рубежа IV-V вв. система расселения резко меняется. За короткий срок почти вся котловина покрывается сетью каменных крепостей [12, с. 49-63]. Заметим, что изменения хронологически совпадают с выдвижением персидской оборонительной линии в районе Дарьяла. Вполне закономерным представляется тогда полагаемое переселение Хазарским каганатом в район Дарьяла и на Северский Донец алан именно из Кисловодской котловины. Оно укрепляло границы самого каганата, одновременно ослабляя военные, торговые и хозяйственные позиции алан в глубине северокавказских территорий. На севере аланы вновь будут нести службу, использующую систему крепостей.

\section{ЛИТЕРАТУРА}

1. Албегова 3.X. Забытое сказание о нартах (к вопросу о миграциях алан в эпоху Хазарского каганата) // Нартоведение в XXI веке: современные парадигмы и интерпретации: Сборник научных трудов. - Владикавказ, 2012. С. 199-214. 2. Албегова 3.Х., Верещинский-Бабайлов Л.И. Раннесредневековый могильник Мамисондон: результаты археологических исследований 2007-2008 ге. в зоне строительства водохранилища Зарамагских ГЭС. - М: Институт археологUи PAH: ТАУС, 2010. 492 c.

3. Алемань А. Аланы в древних и средневековых письменных источниках. - М.: Менеджер, 2003. 608 с.

4. Габриелян P.A. Армяно-аланские отношения (I-X вв.). Ереван: Издательство АН АрмССР, 1989. 143 с.

5. Гаджиев М.C. Хумара: некоторые строительные параллели и проблема датировки укреплений // Очерки средневековой археологии Кавказа: к 85-летию со дня рождения В. А. Кузнецова: сборник статей. - М., 2013. С. 51-65.

6. Дзатmиаты Р.Г. Алано-сасанидские отношения по материалам археологических раскопок в Южной Осетии //
Аланы и Кавказ. ALANICA-II. - Владикавказ, Цхинвал, 1992. C. 71-82

7. Еремян C.T. Сюния и оборона Сасанидами кавказских проходов // Известия Академии наук СССР. Армянский фрилиал. Ереван, 1941. № 7 (12). С. 33-40.

8. Ибн Хордадбех. Книга путей и стран. Перевод с арабского, комментарии, исследование, указатели и карты Наили Велихановой. - Баку: Элм, 1986. 428 с.

9. Из сочинения Я“куби «История». Перевод П. К. Жузе // Материалы по истории Азербайджана. Баку: Издание Общества Обследования и Изучения Азербайджана, 1927. Вып. IV. 34 c.

10. Из Тарих-ал-Камиль (Полного свода истории) Ибн-алАсира. Перевод П. К. Жузе // Материалы по истории Азербайджана. Баку: Издательство АзФАН, 1940. 184 с.

11. Ковалевская В.Б. Кавказ - скифы, сарматы, аланы I тыс. до н. э. - I тыс. н. э. Пущино: ОНТИ ПНЦ РАН, 2005. 398 c.

12. Коробов Д.С. О времени появления алан в Кисловодской 
котловине // Скифо-аланское наследие Кавказа. Сборник научных трудов. - Владикавказ, 2017. С. 48-74

13. Кузнецов В.А. Очерки истории алан. - Владикавказ: Ир, 1992. 392 c.

14. Кузнецов В.А. Еще раз о древнем укреплении в Касарской теснине (Северная Осетия) // Вестник ВНЦ. Владикавказ, 2004. T. 4. № 2. C. 2-7.

15. Кузнецов B.A., Романова Г.Б. "LimesCaucasus» // Первая Абхазская Международная археологическая конференция: Материалы. Посвящена памяти Ю.Н. Воронова. Древние культуры Кавказского Причерноморья, их взаи модействие с культурами соседних регионов. Сохранение культурного наследия. -Сухум, 2006. С. 43-54.

16. Мамаев Х.М. Некоторые вопросы интерпретации раннесредневековых монетных находок Центрального и Северо-Восточного Кавказа // Археология и вопросы хозяйственно-экономической истории Северного Кавказа. Грозный, 1987. С. 47-54.

17. Мастыкова А.В. Женский костюм Центрального и Западного Предкавказья в коние IV - середине VI в. н. э. М.: ИA $P A H, 2009.502$ c.

18. Мишин Д.Е. Хосров I Ануширван (531-579), его эпоха и его жизнеописание и поучение в истории Мискавейха. - М.: ИВ РАН, 2014. 696 с

19. Прокопенко Ю.А., Чаплыгина С.Ф. Центральное Предкавказье в пространстве влияния Великого Шелкового пути и других транскавказских торговых магистралей в V - начале XIII в. - Ставрополь: Печатный Двор, 2017. 272 с. 20. Сведения арабских писателей о Кавказе, Армении и Адербайджане. II. Ибн-ал-Факих. Перевод и примечания Н. А. Караулова // Сборник материалов для описания местностей и племен Кавказа. Тифллис, 1902. Вып. XXXI. Omд. I. C. 1-57.
21. Тменов В.Х. Зодчество средневековой Осетии. - Владикавказ: РИПП им. В. А. Гассиева, 1996. 437 с.

22. Флёров В.С. "Города» и «замки» Хазарского каганата. Археологическая реальность. - М.: Мосты культуры, 2010. $260 \mathrm{c}$

23. Цуциев А.А. Сасанидские монеты в археологических памятниках севера и юга Осетии // Материалы международной научной конференции «Этногенез и этническая история осетин»: Сборник статей. - Цхинвал, 2014. С. 56-59.

24. Цуциев А.А. Восточные предметы в аланских памятниках горной Осетии // Историко-культурное наследие Великого шелкового пути и продвижение туристских дестиниций на Северном Кавказе: материалы Международной научно-практической конференции (Ставрополь 28-29 сентября 2015 г.). - Ставрополь, 2016. С. 137-140.

25. Alexidzé Z. La Construction de la K^EILOYPAd'apres le nouveau manuscript sinaïtique No. 50 // TravauxetMémoires du Centre de Recherché d'histoire et civilization de Byzance. Monographies. T. 13. Paris, 2000. P. 673-681.

26. Harmatta J. The Wall of Alexander the Great and the Limes Sasanicus // Bullet in of the Asia Institute. Studiesin the Honor of Vladimir A. Livshits. 1996. Vol. 10. P. 79-84.

27. Incerti Auctoris Chronicon Pseudo-Dionysianum vulgo dictum. I // Corpus Scriptorum Christianorum Orientalium, 91. Scriptores Syri, 43. Paris: E Typographeo Reipublicae, 1927. 255 p.

28. Ioannes Lydus // Corpus Scriptorum Historiae Byzantinae. Bonnae: Impensised. Webery, MDCCCXXXVIII. LXIV.

29. Minorsky V. A History of Sharvān and Darband in the 10th-11th centuries. Cambridge: W. Heffer\&sons LTD, 1958. VII+187+32p.

\title{
THE FRONTIERS OF THE CAUCASUS IN THE HISTORY OF THE ALANS
}

\author{
A.A. Tuallagov \\ Dr. Head of the Department of Archeology of the V. I. Abaev North Ossetian Institute \\ for Humanitarian and Social Studies - the Filial of the Vladikavkaz Science Centre of \\ the Russian Academy of Sciences (IHSS VSC RAS) (alan167@mail.ru).
}

\begin{abstract}
The article deals with the issue of the defensive limes in the Caucasus that had been created by Persians and then by Arabs and Khazars and had an impact on the history of the Alans. The involvement of the Alans, who had had their own experience in creating defense areas, to protection and custom service contributed to the geographical extention of the residence; interethnic, cultural, politico-military and other interactions that affected the development of the Alanian society itself. It contributed to the intensification of the Caucasian mountainous areas inclusion to the places of permanent residence of the Alans.
\end{abstract}

Keywords: limes, Alans, Persians, archaeological data.

\section{REFERENCES}

1. Albegova Z. Kh. The Forgotten Tale of the Narts (to the question of migration of the Alans in the epoch of Khazar Khaganate) // Nartology in the XXI century: modern paradigms and interpretations. Vladikavkaz, 2012. P. 199-214.

2. Albegova Z. Kh., Vereshchinsky-Babailov L. I. Early Medieval burial ground Mamisondon: the results of archaeological research in 2007-2008 in the construction zone of the reservoir of Zaramag hydro power. Moskow: Institute of Archeology of the Russian Academy of Sciences: TAUS, 2010. $492 p$.

3. Aleman A. Alans in ancient and medieval written sources. Moscow: Manager, 2003. 608 p.

4. Gabrielyan, R. A. Armenian-Alanian relations (1st-10th centuries). Erevan: Publishing house of Academy of Sciences of Armenian SSR, 1989. $143 p$.

5. Gadzhiev M. S. Khumara: some building parallels and the problem of dating of the fortifications // Essays on medieval archeology of the Caucasus: to the 85th anniversary of the birth of Vladimir A. Kuznetsov: collection of articles. Moscow, 2013. P. 51-65.

6. Dzattiata R.G.Alano-Sasanid relations on the materials of archaeological excavations in South Ossetia // Alans and the Caucasus. ALANICA-II.Vladikavkaz, Tskhinval, 1992. P. 71-82.

7. Eremyan S. T. Syunia and the Sassanid Defense of the Caucasian passages // Proceedings of the USSR Academy of Sciences. Armenian branch.Erevan, 1941.№ 7 (12). P. 33-40.

8. Ibn Khordadbekh. Book of paths and countries. Translation from Arabic, comments, research, indexes and maps of NailiVelikhanova. Baku: Elm, 1986. 428 p.

9. From the opus of Ya'qubi "History». Translation of P. K. Zhuze // Materials on the history of Azerbaijan. Baku: Publication of the Society for Survey and Study of Azerbaijan, 1927. Iss. IV. 34 p. 
10. From Tarih-al-Kamil (Complete History) of Ibn al-Asir. Translation of P. K. Zhuze // Materials on the history of Azerbaijan. Baku: Publishing House AzFAN, 1940. 184 p.

11. Kovalevskaya V. B. Caucasus - Scythians, Sarmatians, Alans of the I Millennium BC-I Millennium AD. Pushchino: ONTI PNC RAS, 2005. 398 p.

12. Korobov D. S. About the time of the appearance of the Alans in the Kislovodsk hollow // The ScythianAlanic heritage of the Caucasus. Collection of scientific papers. Vladikavkaz, 2017. P. 48-74.

13. Kuznetsov V. A. Essays on the history of the Alans. Vladikavkaz: Ir, 1992. 392 p.

14. Kuznetsov V. A. Once again about the ancient fortification in the Kasar gorge (North Ossetia) // Bulletin of the VSC. Vladikavkaz, 2004. T. 4. № 2. P. 2-7.

15. Kuznetsov V. A., Romanova G. B. "Limes Caucasus» // First Abkhazian International Archaeological conference: Proceedings. Dedicated to the memory of Yu. N. Voronov. The ancient cultures of the Caucasian Black Sea region, their interaction with the cultures of neighboring regions. The preservation of cultural heritage. Sukhum, 2006. P. 43-54.

16. Mamaev Kh. M. Some problems of interpretation of Early Medieval coin finds in Central and NorthEastern Caucasus // Archaeology and questions of the economic history of the North Caucasus. Grozny, 1987. P. 47-54.

17. Mastykova A. V. Women's costume of the Central and Western Ciscaucasia in the late IV-mid-VI centuries AD. Moscow: Institute of Oriental Studies RAS, 2009. 502 p.

18. Mishin D. E. Khosrow I Anushirvan (531-579), his epoch and his biography and teaching in the history of Miskaveikh. Moscow: Institute of Oriental Studies RAS, 2014. 696 p.

19. Prokopenko Yu. A. Chaplygina S. F. Central Ciscaucasia in the area of influence of the Great Silk Road and other trans-Caucasian trade routes in the V-beginning of the XIII centuries. Stavropol: Printed Yard, 2017. $272 p$.

20. Information of Arab writers about the Caucasus, Armenia and Aderbayjan. II. Ibn al-Faqikh. Translation and notes by N.A. Karaulov // Collection of materials for the description of the localities and tribes of the Caucasus. Tiflis, 1902.Iss. XXXI. P. I. P. 1-57.

21. Tmenov V. Kh. Architecture of medieval Ossetia. Vladikavkaz: RIPP named after V. A. Gassiev, 1996. $437 p$

22. Flyerov V. S. "Cities» and "castles» of the Khazar Khaganate. Archaeological reality. Moscow: Bridges of culture, 2010. 260 p.

23. Tsutsiev A. A. Sasanian coins in the archaeological monuments of North and South Ossetia // Materials of international scientific conference "Ethnogenesis and ethnic history of the Ossetians». Tskhinval, 2014. P. 56-59.

24. Tsutsiev A. A. Eastern objects in the Alanian monuments of the mountainous part of Ossetia // Historical and cultural heritage of the Great Silk Road and promotion of tourist destinations in the North Caucasus: materials of the International Scientific and Practical Conference (Stavropol September 2829, 2015). Stavropol, 2016. P. 137-140.

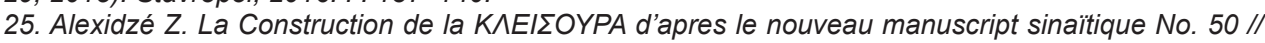
Travauxet Mémoires du Centre de Recherché d'histoire et civilization de Byzance. Monographies. T. 13. Paris, 2000. P. 673-681.

26. Harmatta J. The Wall of Alexander the Great and the Limes Sasanicus // Bulletin of the Asia Institute. Studies in the Honor of Vladimir A. Livshits. 1996. Vol. 10. P. 79-84.

27. Incerti Auctoris Chronicon Pseudo-Dionysianum vulgo dictum. I // Corpus Scriptorum Christianorum Orientalium, 91. Scriptores Syri, 43. Paris: E Typographeo Reipublicae, 1927. 255 p.

28. Ioannes Lydus // Corpus Scriptorum Historiae Byzantinae. Bonnae: Impensis ed. Webery, MDCCCXXXVIII. LXIV.

29. Minorsky V. A History of Sharvān and Darband in the 10th-11th centuries. Cambridge: W. Heffer\& sons LTD, 1958. VII.

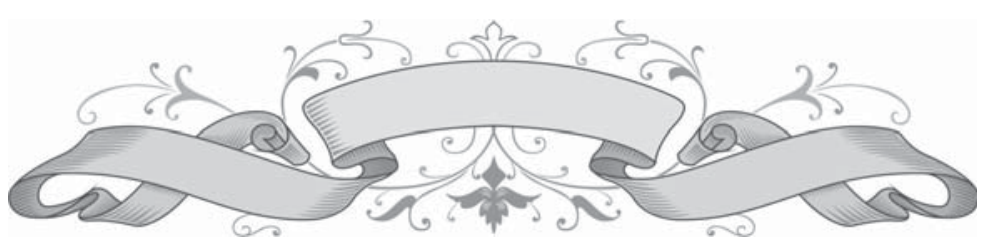

